\title{
PENGADAAN TANAH UNTUK KEPENTINGAN UMUM DALAM KAWASAN \\ TANAH MASYARAKAT HUKUM ADAT
}

\author{
Oleh : \\ Rusmini, SH., MH \\ (Dosen Tetap Sekolah Tinggi Ilmu Hukum Sumpah Pemuda Palembang)
}

Hj.Yonani, SH., MH

(Dosen Tetap FH Universitas Muhammadiyah Palembang)

\begin{abstract}
ABSTRAK
Pengadaan tanah untuk kepentingan umum acap kali tidak "melihat" kenyataan yang berlaku di masyarakat terutama terhadap penggarap tanah yang di atasnya terdapat hak masyarakat hukum adat atau ulayat yang cenderung tidak mempunyai surat bukti pemilikan tanah berupa sertifikat tanah. Mengingat arti pentingnya tanah ulayat bagi masyarakat hukum adat setempat serta mempertimbangkan adanya nilal-nilai religius-magis yang melekat kuat pada tanah tersebut, pengambilalihan tanah ulayat perlu dilakukan dehgan cara dan prosedur tertentu.Jika di hubungkan antara Pasal 6 dan Pasal 18 UUPA di atas, maka kepentingan umum sebagai salah satu bentuk fungsi sosial dapat dijadikan salah satu alasan pembenar pencabutan hak atas tanah (termasuk hak komunal atas tanah) oleh Negara dengan syarat tertentu yaitu dengan memberi ganti rugi yang layak dan menurut cara yang diatur dengan Undang- Undang. Exesistensi hak masyarakat hukum adat berkenaan pihak yang berhak menerima ganti rugi.terdapat dalam penjelasan Pasal 40 huruf (e) Undang-Undang No.2 Tahun 2012 Tentang Pengadaan Tanah Bagi Pembangunan Untuk Kepentingan Umum
\end{abstract}

Kata Kunci : pengadaan tanah, kepentingan umum,masyarakat hokum adat

\section{ABSTRACT}

Land acquisition for the public interest often does not "see" the reality prevailing in the community, especially for land tenants upon whom there are customary or customary community rights that tend not to have proof of land ownership in the form of land certificates. Considering the importance of customary land for local customary law communities and considering the existence of religious-magical values that are strongly attached to the land, the acquisition of customary land needs to be done in certain ways and procedures. If connected between Article 6 and Article 18 of the LoGA above, then the public interest as a form of social function can be used as one of the reasons for the revocation of land rights (including communal rights to land) by the State with certain conditions, namely by providing appropriate compensation and in a manner regulated by law. Existence of the rights of indigenous and tribal peoples regarding parties entitled to receive compensation. Found in the explanation of Article 40 letter (e) of Law No. 2 of 2012 concerning Land Procurement for Development in the Public Interest

Keywords: land acquisition, public interest, customary law community 


\section{A. Latar Belakang}

Negara Indonesia merupakan salah satu negara agraris, sehingga tanah mempunyai arti yang sangat penting bagi kehidupan rakyat Indonesia. Tanah sebagai unsur sumber daya alam mempunyai fungsi yang penting untuk membangun masyarakat Indonesia yang adil dan makmur. Hampir semua kegiatan manusia berkaitan dengan tanah, dalam kegiatan sehari-hari manusia memerlukan tempat tinggal,tempat untuk berusaha dan tempat peribadatan dan lainlain. Dengan demikian maka jelaslah bahwa tanah sebagai sumber utama bagi kehidupan manusia, yang telah dikaruniakan oleh Tuhan Yang Maha Esa sebagai tumpuan masa depan kesejahteraan manusia itu sendiri.

Tanah dalam pengertian yuridis adalah permukaan bumi, hak atas tanah adalah hak atas sebagian tertentu dari permukaan bumi, yang terbatas, berdimensi dua dengan ukuran panjang dan lebar. ${ }^{63}$ Disisi lain, pembangunan khususnya untuk kepentingan umum yang juga membutuhkan tanah dalam jumlah yang tidak sedikit. Tanpa adanya ketersediaan tanah yang memadai, program pembangunan untuk kepentingan umumyang sudah direncanakan tidak dapat berjalan dan proyek pembangunan yang sedang bertangsung akan terhenti.

Adanya perbedaan pengertian konsep kepentingan umum antara Undang-Undang Nomor 5 tahun 1960 tentang Peraturan Dasar Pokok-Pokok Agraria yang sebelumnya menjadi landasan hukum soal pertanahan dengan aturan yang terbaru yakni UU No 2 Tahun 2012 Tentang Pengadaan Tanah Bagi Pembangunan Untuk Kepentingan Umum. Dalam UU No.5 Tahun 1960, konsep kepentingan umum tidak disebutkan secara jelas. Istilah kepentingan umum hanya digunakan sebagai legitimasi tindakan negara untuk mencabut hak rakyat atas tanah. Hal itu termaktub dalam Pasal 18 yang menyatakan bahwa : untuk kepentingan umum termasuk kepentingan bangsa dan negara serta kepentingan bersama dari rakyat, hak-hak atas tanah dapat dicabut dengan memberi ganti kerugian yang layak dan menurut cara yang diatur dengan undang-undang.

Hal itu berbeda dengan UU No.2 Tahun 2012 Pengadaan Tanah Bagi Pembangunan Untuk Kepentingan Umum yang menyebutkan secara jelas pengertian kepentingan umum dalam pasal 1 ayat 6 sebagai kepentingan bangsa, negara, dan masyarakat yang harus diwujudkan oleh pemerintah dan digunakan sebesar-besarnya untuk kemakmuran rakyat. Untuk itu, disinilah kita perlu kembali memahami esensi dasar dari kepentingan umum seperti yang termaktub dalam UU No. 22 tahun 2012 tersebut.

${ }^{63}$ Effendi Perangin. Hukum Agraria Indonesia, Suatu Telaah Dari Sudut Pandang Praktisi Hukum. Raja Grafindo. Jakarta, 1994. Hlm 17. 
Dalam rangka penyediaan tanah untuk pembangunan kepentingan umum, tanah yang berstatus hak milik maupun tanah milik masyarakat hukum adat atau tanah ulayat sering ikut dikorbankan

Pengertian hak ulayat secara umum adalah :

Hak persekutuan hukum/masyarakat desa untuk menggunakan dan mengolah tanahtanah yang berada di sekeliling desa mereka, guna untuk memenuhi kepentingan persekutuan hukum itu, atau untuk kepentingan orang yang berada diluar dari persekutuan hukum/masyarakat desa itu dengan mengerjakan tanah itu dengan memberikan sebagian dari hasilnya kepada masyarakat. ${ }^{64}$

Sedangkan pemgertian kepentingan umum yang terdapat dalam Pasal 1 Undangundang Nomor 20 tahun 1961 dijelaskan kepentingan umum dalam arti peruntukannya, yaitu untuk kepentingan bangsa dan negara, kepentingan bersama dari rakyat dan kepentingan pembangunan. Sehingga dapat disimpulkan bahwa yang dimaksud dengan kepentingan umum adalah kepentingan tersebut harus memenuhi peruntukkannya dan harus dirasakan kemanfaatannya, dalam arti dapat dirasakan oleh masyarakat secara keseluruhan dan secara langsung.

Menurut ketentuan dalam Pasal 1 angka 3 Keppres Nomor 55 Tahun 1993, yang dimaksud dengan kepentingan umum adalah "kepentingan untuk seluruh lapisan masyarakat". Ketentuan ini hanya untuk pemenuhan kebutuhan tanah bagi pelaksanaan pembangunan untuk kepentingan umum.

Sehingga nemurut Keppres Nomor 55 Tahun 1993, kriteria kepentingan umum, dibatasi :

a. Dilakukan oleh pemerintah,

b. Dimiliki oleh pemerintah,

c. Tidak untuk mecari keuntungan.

Menurut ketentuan dalam Pasal 1 angka 5 Perpres Nomor 36 Tahun 2005, yang dimaksud dengan kepentingan umum adalah "kepentingan sebagian besar lapisan masyarakat". Ketentuan ini berbeda dengan ketentuan sebelumnya dalam Keppres Nomor 55 Tahun 1993 yang mengatur tentang kepentingan untuk seluruh lapisan masyarakat. Kemudian menurut Undang-undang Nomor 2 Tahun 2012, yang dimaksud dengan kepentingan umum adalah "kepentingan bangsa, negara, dan masyarakat yang harus diwujudkan oleh pemerintah dan dugunakan sebesar-besarnya untuk kemakmuran rakyat."

Hal penting yang perlu diperhatikan dalam pengadaan tanah bagi kepentingan umum adalah peralihan status hak atas tanah dari pihak pemilik tanah kepada pihak instansi yang

${ }^{64}$ Simorangkir dkk, Kamus Hukum, Aksara Baru,Jakarta, 1997,hlm.61 
membutuhkan tanah dengan mekanisme ganti rugi, maka dengan demikian, poin pentingnya adalah sipemilik tanah harus terlebih dahulu dapat membuktikan bahwa dirinya adalah satusatunya pihak yang berhak menerima ganti rugi dan mengalihkan hak atas tanahnya kepada instansi yang membutuhkan tanah bukti kepemilikan dan/atau penguasaan tanah dalam hukum pendaftaran tanah sebagaimana diatur dalam Peraturan Pemerintah Nomor 24 Tahun 1997 tentang Pendaftaran Tanah.

Pengadaan tanah untuk kepentingan umum acap kali tidak "melihat" kenyataan yang berlaku di masyarakat terutama terhadap penggarap tanah yang di atasnya terdapat hak masyarakat hokum adat yang cenderung tidak mempunyai surat bukti pemilikan tanah berupa sertifikat tanah. Kepemilikan tanah dalam masyarakat hukum adat terjadi secara ipso facto,artinya tanah dipandang sudah dikuasai apabila secara kasat inderawi telah nyata- nyata ditempati, dimanfaatkan dan diusahakan serta dirawat oleh orang baik sebagai pemukim atau penggarap. ${ }^{65}$ Hal ini berarti bahwa kepastian hukum pemilikan tanah dalam hukum adat, tidak dapat dipahami menurut perspektif ipso jure sebagaimana yang dikehendaki oleh UUPA,melainkan harus dipahami menurut perspektif hukum adat itu sendiri.

Memahami kepastian hukum pemilikan tanah dalam hukum adat dengan menggunakan perspektif peraturan perundang-undangan, mengakibatkan kepemilikan tanah berdasarkan hukum adat menjadi tidak diakui.Hal ini dikarenakan pemiliknya tidak dapat memperlihatkan adanya cukup bukti hak atas tanah sebagaimana yang diatur dalam peraturan perundang-undangan.

Selain itu permasalahan pertanahan dapat juga muncul dikarenakan adanya berbagai peraturan perundang-undangan yang memfasilitasi sektor pemerintah maupun sektor swasta untuk memperoleh tanah dalam rangka melaksanakan kegiatan usahanya Pada konteks alas hak sebagai bukti kepemilikan dan/ atau penguasaan tanah dalam kegiatan pengadaan tanah untuk kepentingan umum inilah kemudian eksistensi hak komunal menjadi variable penting untuk diteliti.

\section{B. Permasalahan}

Fokus permasalahan dalam penulisan ini adalah bagaimana pelaksanaan pengadaan tanah untuk kepentingan umum dalam kawasan tanah masyarakat hukum adat ?

${ }^{65}$ Soetandyo Wignyosoebroto, Tanah Negara, Tanah Adat yang Dinasionalisasi, Elsam, Jakarta, 1996, 


\section{Pembahasan}

Dalam hukum adat hak penguasaan atas tanah yang tertinggi adalah hak ulayat, sebagaimana tanah bersama para warga masyarakat hukum adat yang bersangkutan, yang mengandung dua unsur aspek hukum keperdataan dan hukum publik. Subyek hak ulayat ialah masyarakat hukum adat, baik territorial, genealogik, maupun genealogis territorial sebagai bentuk bersama para warganya. ${ }^{66}$

Pengaturan hak masyarakat hokum adat atau dikenal hak ulayat diatur dalam Pasal 3 UU.No. 5 Tahun 1960 Tentang Peraturan Dasar Pokok-Pokok Agraria atau dikenal UndangUndang Pokok Agraria (UUPA) menentukan :

“Dengan mengingat ketentuan-ketentuan dalam Pasal 1 dan 2, pelaksanaan hak ulayat dan hak-hak yang serupa itu dari masyarakat-masyarakat Hukum Adat, sepanjang menurut kenyataannya masih ada, harus sedemikian rupa, sehingga sesuai dengan kepentingan nasional dan negara berdasarkan atas persatuan bangsa, serta tidak boleh bertentangan dengan Undang-undang dan peraturan-peraturan (hukum) lain yang lebih tinggi".

Pasal 3 UUPA mengakui keberadaan hak ulayat, tetapi pengakuan terhadap hak ulayat oleh UUPA disertai dengan dua syarat yaitu mengenai "eksistensinya" dan mengenai "pelaksanaannya". "Eksistensi" artinya selama tanah-tanah hak ulayat dari suatu masyarakat hukum adat masih ada maka keberadaannya tersebut diakui oleh UUPA dan "pelaksanaanya" artinya penggunaan dari tanah hak ulayat tersebut nantinya tidak bertentangan dengan kepentingan nasional dan negara.

Pengakuan hak ulayat dalam Pasal 3 UU.No. 5 Tahun 1960 UUPA menjadi dasar yang kuat bagi kelompok masyarakat adat untuk menguasai, mengatur dan memanfaatkan tanah-tanah ulayatnya.

Namun demikian, pengakuan terhadap hak ulayat masih ada atau tidak, diatur melalui Pasal 2 ayat (2) Peraturan Menteri Negara Agraria/Kepala BPN No.5 Tahun 1999 Tentang Pedoman Penyelesaian Masalah Hak Ulayat Masyarakat Hukum Adat, yakni:

a. terdapat sekelompok orang yang masih merasa terikat oleh tatanan hukum adatnya sebagai warga bersama suatu persekutuan hukum tertentu, yang mengakui dan menerapkan ketentuan-ketentuan persekutuan tersebut dalam kehidupannya sehari-hari,

b. terdapat tanah ulayat tertentu yang menjadi lingkungan hidup para warga persekutuan hukum tersebut dan tempatnya mengambil keperluan hidupnya sehari-hari,dan

${ }^{66}$ R. Supomo, Bab-bab tentang hukum adat. Penerbitan universitas, Jakarta, 2012,hlm.41 
c. terdapat tatanan hukum adat mengenai pengurusan, penguasaan dan penggunaan tanah ulayat yang berlaku dan ditaati oleh para warga persekutuan hukum tersebut

Meskipun secara visual keberadaan tanah masyarakat hukum adat dapat dilihat, namun secara legal formal masyarakat adat tidak memiliki atau tidak dapat menunjukkan bukti, misalnya berupa sertifikat atau surat register yang menyatakan bahwa tanah adat yang bersangkutan telah dikuasainya secara turun temurun selama bertahun-tahun, hal ini dikarenakan berdasarkan Pasal 4 ayat (1) UU No. 5 Tahun 1960 tentang Peraturan Dasar Pokok-Pokok Agraria (UUPA), subyek hukum yang dapat memiliki hak atas tanah adalah orang-orang, baik sendiri maupun bersama-sama dengan orang-orang lain serta badan-badan hukum.

Dengan demikian, berdasarkan Pasal 4 ayat (1) UUPA, masyarakat adat yang bersifat komunal bukan merupakan subyek hukum yang dapat memiliki hak atas tanah. Sementara itu pembatasan kepemilikan atas tanah telah diatur dalam Pasal 7 UUPA yang menyebutkan bahwa "untuk tidak merugikan kepentingan umum maka pemilikan dan penguasaan tanah yang melampaui batas tidak diperkenankan.

Pasal 6 UUPA menyebutkan bahwa: "Semua hak atas tanah mempunyai fungsi sosial". Merujuk pada pasal tersebut dapat difahami bahwa penggunaan hak atas sebidang tanah juga harus memperhatikan kepentingan umum meliputi masyarakat,bangsa dan negara. Lebih jauh,Pasal 18 UUPA menyatakan bahwa: "Untuk kepentingan umum, termasuk kepentingan bangsa dan negara serta kepentingan bersama dari rakyat, hak - hak Atas tanah dapat dicabut, dengan memberi ganti rugi yang layak dan menurut cara yang diatur dengan Undang-Undang."

Jika di hubungkan antara Pasal 6 dan Pasal 18 UUPA di atas, maka kepentingan umum sebagai salah satu bentuk fungsi sosial dapat dijadikan salah satu alasan pembenar pencabutan hak atas tanah (termasuk hak komunal atas tanah) oleh Negara dengan syarat tertentu yaitu dengan memberi ganti rugi yang layak dan menurut cara yang diatur dengan Undang- Undang.

Exesistensi hak masyarakat hukum adat berkenaan pihak yang berhak menerima ganti rugi.terdapat dalam penjelasan Pasal 40 huruf (e) No.2 Tahun 2012 Tentang Pengadaan Tanah Bagi Pembangunan Untuk Kepentingan Umum adalah sebagai berikut; " Pemberian ganti kerugian pada prinsipnya harus diserahkan langsung kepada pihak yang berhak atas ganti kerugian. Apabila berhalangan,p ihak yang berhak karena hokum dapat memberikan kuasa Kepada pihak lain atau ahli waris. 
Penerima kuasa hanya dapat menerima kuasa dari satu orang yang berhak atas ganti kerugian. Yang berhak antara lain:
a. Pemegang hak atas tanah;
b. Pemegang hak pengelolaan;
c. nadzir,untuk tanah wakaf;
d. pemilik tanah bekas milik adat;
e. masyarakat hokum adat;
f. pihak yang menguasai tanah Negara dengan itikad baik;
g. pemegang dasar penguasaan atas tanah;dan/ atau
h. .pemilik bangunan,tanaman atau benda lain yang berkaitan dengan tanah...”

Merujuk pada penjelesan tersebut di atas,dapat difahami bahwa UU No. 2 Tahun 2012 Tentang Pengadaan Tanah Bagi Pembangunan Untuk Kepentingan Umum memandang keberadaan hak komunal sebagai sebuah lembaga hokum kedudukannya sederajat dengan hak atas tanah lainnya yang lahir berdasarkan UUPA dan PP No. 24 Tahun 1997 tentang Pendaftaran Tanah serta memiliki hak dan kewajiban yang seimbang dalam posisi objek pengadaan tanah.

Pengadaan tanah bagi pembangunan untuk kepentingan umum merupakan bentuk lain dari fungsi sosial hak atas tanah yang esensinya adalah terlaksananya pembangunan dalam upaya mencapai dan meningkatkan kesejahteraan rakyat.

Batasan kepentingan umum selanjutnya dapat dilihat pada Pasal 1 ayat 6 UU No.2 Tahun 2012 Tentang Pengadaan Tanah Bagi Pembangunan Untuk Kepentingan Umum yaitu; "bahwa kepentingan umum adalah kepentingan bangsa,negara,dan masyarakat yang harus diwujudkan oleh pemerintah dan digunakan sebesar -besarnya untuk kemakmuran rakyat.”

Adapun ruang lingkup kepentingan umum dimaksud adalah kepentingan yang digunakan untuk pembangunan sebagaimana diatur dalam Pasal 10 UU No.2 Tahun 2012,yaitu:

a. Pertahanan dan keamanan Nasional;

b. Jalan umum,jalan tol,terowongan,jalur kereta api,stasiun kereta api,dan fasilitas operasi kereta api;

c. Waduk, bendungan,bendung, irigasi,saluran air minum,saluran pembuangan air dan sanitasi,dan bangunan pengairan lainnya;

d. Pelabuhan,Bandar udara,dan terminal;

e. Infrastruktur minyak,gas,dan panas bumi; 
f. Pembangkit,transmisi,gardu,jaringan dan distribusi tenaga listrik;

g. Jaringan telekomunikasi dan informatika pemerintah;

h. Tempat pembuangan dan pengelolahan sampah;

i. Rumah sakit pemerintah/pemerintah daerah;

j. Fasilitas keselamatan umum;

k. Tempat pemakaman umum pemerintah/pemerintah daerah;

1. Fasilitas sosial,fasilitas umum dan ruang terbuka hijau publik;

m. Cagar alam dan cagar budaya;

n. Kantor Pemerintah/Pemerintah Daerah/ Desa;

o. Penataan pemukiman kumuh perkotaan dan/ atau konsolidasi tanah,serta perumahan untuk masyarakat berpenghasilan rendah dengan status sewa;

p. Prasarana pendidikan atau sekolah pemerintah/pemerintah daerah;

q. Prasarana olah raga pemerintah/pemerintah daerah;dan

r. Pasar umum dan lapangan parkir.

Dengan demikian, ruang lingkup kepentingan umum dimaksud di atas memberi batasan bahwa pembangunan di luar kepentingan - kepentingan sebagaimana telah digariskan pada Pasal 10 UU No. 2 Tahun 2012 adalah bukan merupakan kepentingan umum,oleh karenanya proses pengadaan tanahnya bukanlah bagian dari lingkup pengadaan tanah bagi pembangunan untuk kepentingan umum sebagaimana dimaksud dalam UU No. 2 Tahun 2012.

Sehubungan dengan kepentingan umum di atas hak tanah masyarakat hokum adat jika merujuk pada Pasal 5 UUPA menyebutkan bahwa; "Hukum agrarian yang berlaku atas bumi,air dan ruang angkasa ialah hokum adat,sepanjang tidak bertentangan dengan kepentingan Nasional dan Negara",maka atas dasar persatuan bangsa,dengan sosialisme Indonesia serta dengan peraturan -peraturan yang tercantum dalam UUPA,memiliki konsekuenasi bahwa setiap hal mengenai tanah dan pertanahan termasuk tanah ulayat harus sesuai dengan kepentingan nasional dan Negara.

Kepentingan umum selanjutnya dapat dilihat pada Pasal 1 ayat 6 UU No. 2 Tahun 2012 yaitu bahwa Kepentingan Umum adalah kepentingan bangsa,negara,dan masyarakat yang harus diwujudkan oleh pemerintah dan digunakan sebesar - besarnya untuk kemakmuran rakyat. Oleh karena itu landasan yuridis dari pencabutan sebidang tanah hak masyarakat hukum adat harus menggunakan alasan kepentingan umum 


\section{Penutup}

\section{Kesimpulan}

Pada Pasal 6 dan Pasal 18 UUPA di atas, maka kepentingan umum sebagai salah satu bentuk fungsi sosial dapat dijadikan salah satu alasan pembenar pencabutan hak atas tanah (termasuk hak komunal atas tanah) oleh Negara dengan syarat tertentu yaitu dengan memberi ganti rugi yang layak dan menurut cara yang diatur dengan Undang- Undang.

Exesistensi hak masyarakat hukum adat berkenaan pihak yang berhak menerima ganti rugi.terdapat dalam penjelasan Pasal 40 huruf (e) No.2 Tahun 2012 adalah sebagai berikut; “ Pemberian ganti kerugian pada prinsipnya harus diserahkan langsung kepada pihak yang berhak atas ganti kerugian. Apabila berhalangan,p ihak yang berhak karena hokum dapat memberikan kuasa Kepada pihak lain atau ahli waris.

\section{Saran}

a. Berkaitan dengan Pengakuan yang diberikan oleh Negara kepada hak masyarakat adat, agar lebih menjamin hak masyarakat adat dalam pengelolaan sumberdaya. karena di dalam Undang-Undang hanya memberi bentuk pengakuan saja tetapi tidak menjamin kepemilikan, sementara adat adalah suatu budaya atau kebiasaan dan aturan yang ada sejak dahulu dan sebelum ada peraturan-peraturan Pemerintah oleh karena itu harus memperhatikan hak rakyat demi kesejahteraan rakyat.

b. Perlu dikembangkannya upaya-upaya untuk mempertahankan keberadaan hak masyarakat adat dan keberadaan nilai-nilai hukum adat baik oleh pemerintah maupun masyarakat

\section{DAFTAR PUSTAKA}

Effendi Perangin. Hukum Agraria Indonesia, Suatu Telaah Dari Sudut Pandang Praktisi Hukum.Raja Grafindo. Jakarta, 1994

R. Supomo, Bab-bab tentang hukum adat. Penerbitan universitas, Jakarta, 2012

Simorangkir dkk, Kamus Hukum, Aksara Baru,Jakarta, 1997

Soetandyo Wignyosoebroto, Tanah Negara, Tanah Adat yang Dinasionalisasi, Elsam, Jakarta, 1996 